\title{
Detection of Organic Hydroperoxides in Rabbit Lung Lavage Fluid, but not in Lung Tissue Homogenate, Using GSH Peroxidase and GSH Reductase
}

\author{
By W. Seeger, L. Róka and U. Moser \\ Institut für Klinische Chemie und Pathobiochemie (Prof. Dr. L. Róka)/ \\ Zentrum für Innere Medizin (Prof. Dr. Dr. H. G. Lasch), Justus-Liebig-Universität Gießen
}

(Received May 18/July 10, 1984)

Herrn Professor Dr. L. Róka von seinen Co-Autoren zum 65. Geburtstag gewidmet

\begin{abstract}
Summary: A specific method for the detection of organic hydroperoxides in lung lavage fluid (lung surfactant system) and lung tissue homogenate is described. After the inactivation of endogenous GSH peroxidase and GSH reductase and preincubation with catalase, organic hydroperoxides are consumed by addition of GSH and GSH peroxidase. The increase of GSSG, compared to a blank without addition of GSH peroxidase, is measured in a second enzymatic step with GSH reductase. The recoveries of $t$-butyl hydroperoxide and of peroxidized, free fatty acids added to lavage fluid or to lung homogenate are higher than $85 \%$ in each case. The detection limits of this assay for organic hydroperoxides are $0.9 \mathrm{nmol} / \mathrm{mg}$ surfactant phospholipid (molar ratio of 0.00066 ) and $40 \mathrm{nmol} / \mathrm{g}$ wet lung weight. The assay detects organic hydroperoxides in the surfactant system of normal rabbit lungs, but not in lung tissue homogenate.
\end{abstract}

Messung organischer Hydroperoxide in Kaninchenlungen-Lavageflüssigkeit, aber nicht im LungengewebeHomogenat, mittels GSH-Peroxidase und GSH-Reduktase

Zusammenfassung: Eine spezifische Methode für den Nachweis organischer Hydroperoxide in Lungen-Lavage-Flüssigkeit (Lungen Surfactant System) und Lungengewebe-Homogenat wird beschrieben. Nach Inaktivierung endogener GSSH-Peroxidase und GSH-Reduktase und Präinkubation mit Katalase werden organische Hydroperoxide durch Zusatz von GSH und GSH-Peroxidase metabolisiert. Der Anstieg von GSSG, verglichen mit einem Leerwert ohne Zusatz von GSH-Peroxidase, wird in einem zweiten enzymatischen Schritt mit GSH-Reduktase gemessen. Die Wiederfindung von t-Butyl-hydroperoxid und von peroxidierten freien Fettsäuren nach Zusatz zur Lavage-Flüssigkeit oder zum Gewebe-Homogenat beträgt mehr als $85 \%$. Die Nachweișgrënze dieses Testes für organische Hydroperoxide liegt bei $0,9 \mathrm{nmol} / \mathrm{mg}$ Surfactant-Phospholipid (mollares Verhältnis von 0,00066) und $40 \mathrm{nmol} / \mathrm{g}$ Feuchtgewebe. Der Test weist organische Hydroperoxide im Surfạctantt=System normaler Kaninchenlungen, aber nicht im Gewebehomogenat nach.

\section{Introduction}

There is impressive experimental evidence that oxygen-derived free radicals and (subsequent) peroxidation processes represent a common etiology in lung injury provoked by exposure to toxic levels of oxygen $(1-3)$, oxidizing agents such as $\mathrm{NO}_{2}$ and ozone (4-7) and leukocyte-dependent acute (respi- ratory distress syndrome) and chronic inflammatory events $(8-10)$. In bronchoalveolar lavage fluid from patients with respiratory distress syndrome, obtained by flexible bronchoscopy, Cochrane et al. observed the oxidative inactivation of the $\alpha_{1}$-proteinase inhibitor in this system, thus providing indirect evidence for the presence of oxidants in vivo (11). The detec- 
tion of lipid peroxidation in biological systems is based chiefly on the measurement of their cleavage products: malonaldehyde by the thiobarbituric acid reaction $(12,13)$, fluorescent chromophores $(14,15)$ and recently ethane and pentane by gas chromatography $(16,17)$. Direct measurement of peroxides by UV-detection of conjugated dienes $(18,19)$ and titrimetrical measurement of $\mathrm{I}_{2}$ generated from a $\mathrm{KI}$ solution $(20,21)$ lack specifity in complex biological systems. GSH peroxidase ( $\mathrm{GSH}: \mathrm{H}_{2} \mathrm{O}$ oxidoreductase; EC 1.11.1.9) reduces numerous organic hydroperoxides to their corresponding alcohols, thereby transfering two electrons from the oxidation of GSH to GSSG, which, in a second enzymatic step, is again reduced to GSH by NADPH via GSH reductase (EC 1.6.4.2) (22-26). Preincubation with catalase (EC 1.11.1.6) prior to the addition of GSH peroxidase destroys $\mathrm{H}_{2} \mathrm{O}_{2}$, which would otherwise interfere in the determination of organic hydroperoxides. Biological materials, however, require certain precautions because of the lability of organic hydroperoxides. When applying this enzymatic assay to rabbit lung surfactant system, obtained by bronchoalveolar lavage, and to rabbit lung tissue homogenate, it was found to be advantageous to separate the two enzymatic steps, transforming the organic hydroperoxides to their alcohols as soon as possible in the assay procedure in order to obtain the stable GSSG. In this way exogenously added organic hydroperoxides are recovered $>85 \%$ from the lavage fluid and the tissue homogenate. This assay detects organic hydroperoxides in natural rabbit lung surfactant, but not in lung homogenate.

\section{Materials and Methods}

\section{Reagents}

Lyophilized GSH peroxidase from bovine erythrocytes (EC 1.11.1.9) was a gift from Dr. Wunderwald, Boehringer Mannheim, FRG. The lyophilized material, containing $20 \%$ protein (Biuret), had a specific activity of $0.55 \mathrm{U} / \mathrm{mg}$, measured according to Günzler et al. (27) (with a modified reaction temperature of $25^{\circ} \mathrm{C}$ instead of $37^{\circ} \mathrm{C}$ ). GSH reductase from yeast (EC 1.6.4.2; specific activity $120 \mathrm{U} / \mathrm{mg}$ protein), catalase from bovine liver (EC 1.11.1.6; specific activity $65000 \mathrm{U} / \mathrm{mg}$ protein), GSH and NADPH were purchased from Boehringer Mannheim. Lipoxidase from soybean (EC 1.13.11.12; specific activity 500000 $\mathrm{U} / \mathrm{mg}$ protein) and t-butyl hydroperoxide were obtained from Sigma.

\section{Methods}

The lungs of rabbits of both sexes (body weight $2.2-2.8 \mathrm{~kg}$ ) were excised during deep anaesthesia and the blood was completely removed by rinsing the vascular bed with ice-cold saline. Imme- diately afterwards the lungs were either homogenized or lavaged with $4 \times 25 \mathrm{ml}$ ice-cold saline via a tracheal canula. The phospholipid content of the lavage fluid was determined from its organic phosphorus (28), calculated on the basis of the molecular weight of dipalmitoyl lecithin. It ranged between 250 and $350 \mathrm{mg} / \mathrm{l}$. In vitro measurement of t-butyl hydroperoxide and peroxidized, free fatty acids was carried out according to Heath \& Tappel (25). A mixture of peroxidized, free fatty acids from equal molar amounts of linoleic acid, linolenic acid and arachidonic acid for the measurement of recovery was prepared by incubation with soybean lipoxidase according to Hamberg \& Samuelsson (29). Non-enzymatic lipid peroxidation of the alveolar surfactant material was performed by incubation with $\mathrm{FeCl}_{3}(0.67 \mathrm{mmol} / \mathrm{l})$ and ascorbic acid $(1.33 \mathrm{mmol} / \mathrm{l})$ for $20 \mathrm{~h}$ at $37^{\circ} \mathrm{C}$ according to Dumelin \& Tappel (30).

Measurement of organic hydroperoxides in the alveolar surfactant system and in lung tissue homogenate

Both assay procedures follow the same principle. Each step is performed with ice-cold lavage fluid and tissue homogenate and icecold reagents if not indicated otherwise.

\section{Lavage}

The lavage fluid is centrifuged at $1000 \mathrm{~g}$ for $5 \mathrm{~min}$ (31): Then 1 $\mathrm{mol} / \mathrm{l}$ perchloric acid is added $(0.2 \mathrm{~V}$ of the cell free lavage volume) and after $2 \mathrm{~min}$ is neutralized ( $\mathrm{pH} 7$ ) with the same volume of $1 \mathrm{~mol} / 1 \mathrm{KOH}$. After the addition of $\mathrm{KH}_{2} \mathrm{PO}_{4}$ buffer $(0.25$ $\mathrm{mol} / \mathrm{l} ; \mathrm{pH} 7 ; 2.5 \mathrm{mmol} / \mathrm{EDTA}-0.1 \mathrm{~V} / \mathrm{l}$ of the initial lavage volume) and catalase ( $780 \mathrm{kU} / \mathrm{l}$ initial lavage volume), the mixture is allowed to stand for $10 \mathrm{~min}$, followed by addition of $155 \mathrm{mg} \mathrm{GSH}$ per l initial lavage volume. The total volume is then divided into two identical portions and one portion is incubated at $25^{\circ} \mathrm{C}$ with $0.4 \mathrm{~g}$ lyophilized GSH peroxidase per 1 initial lavage volume. The other portion undergoes the same procedure without addition of GSH peroxidase. After 20 min incubation both portions are immediately spin-frozen, lyophilized and resuspended in a small volume of distilled water (usually $2 \mathrm{ml}$ ). The suspensions are extracted with identical volumes of chloroform, centrifuged briefly and GSSG is determined in the aqueous phases according to Bergmeyer (32). The difference in the GSSG concentration between the two portions of the lavage fluid is used to calculate the amount of organic hydroperoxides. The data are expressed in nmol/mg lavage phospholipid or as the molar ratio of organic hydroperoxides to phospholipid.

\section{Lung tissue homogenate}

Lung tissue is roughly minced and immediately homogenized in $0.5 \mathrm{~mol} / \mathrm{h} \mathrm{HClO}{ }_{4}(2 \mathrm{ml} / \mathrm{g}$ wet weight; time of homogenization about $2 \mathrm{~min}$ ). Then the homogenate is neutralized with $1.75 \mathrm{~mol} / \mathrm{t}$ $\mathrm{K}_{3} \mathrm{PO}_{4}$ and is incubated with catalase $(520 \mathrm{kU} / \mathrm{h}$ homogenate volume) for $5 \mathrm{~min}$. Next GSH is added $(0.7 \mathrm{~g} / \mathrm{l}$ homogenate volume), the total volume is divided and one portion is incubated at $25^{\circ} \mathrm{C}$ with $0.8 \mathrm{~g}$ lyophilized GSH peroxidase per 1 homogenate fluid for $10 \mathrm{~min}$. The other portion is incubated under the same conditions but without GSH peroxidase. Then both portions are immediately cooled to $0{ }^{\circ} \mathrm{C}$, precipitated with $2 \mathrm{~mol} / 1 \mathrm{HClO}_{4}(0.4$ $1 / 1)$ and centrifuged $(4 \mathrm{~min}, 8000 \mathrm{~g}$ ). The supernatants are neutralized with $1.75 \mathrm{~mol} / 1 \mathrm{~K}_{3} \mathrm{PO}_{4}$, centrifuged again $(2 \mathrm{~min}, 8000 \mathrm{~g}$ ) and GSSG is determined in both supernatants according to Bergmeyer (32). The difference in the concentration of GSSG between the stwo homogenate portions is used to calculate the amount of organic hydroperoxides. The data are expressed in nmol hydroperoxide per $g$ wet lung weight.
: 


\section{Results}

\section{Inactivation of endogenous enzymes}

Incubation of the lavage fluid and the lung tissue homogenate with ice-cold perchloric acid (final concentration 0.2 and $0.33 \mathrm{~mol} / \mathrm{l}$ according to the different protein concentrations) for $2 \mathrm{~min}$ and subsequent neutralization with $\mathrm{KOH}$ or $\mathrm{K}_{3} \mathrm{PO}_{4}$ is sufficient to completely inactivate endogenous GSH peroxidase and GSH reductase. The samples are not spun after neutralization, in order to prevent potential loss of lipid material before "converting" the amount of hydroperoxides to GSSG by GSH peroxidase. Organic hydroperoxides are not destroyed by this procedure: $t$-butyl hydroperoxide and a mixture of peroxidized free fatty acids are recovered to $>95 \%$ when submitted to this reaction step.

\section{Addition of phosphate buffer}

The addition of $0.1 \mathrm{l} / \mathrm{h}$ phosphate buffer $(0.25 \mathrm{~mol} / \mathrm{h}$, $\mathrm{pH} 7$ ) to the surfactant system, obtained by lavage with saline, is necessary for the enzymatic activity of GSH peroxidase.

\section{Addition of catalase}

The addition of $520 \mathrm{kU} / \mathrm{h}$ assay volume is sufficient for complete degradation of $>0.3 \mathrm{mmol} / 1 \mathrm{H}_{2} \mathrm{O}_{2}$ in 5 $\min$ at $0^{\circ} \mathrm{C}$.

\section{Addition of GSH}

The amount of GSH added to the lavage fluid and the tissue homogenate should be 5 fold higher than the amount of organic hydroperoxides maximally expected. If the concentration of GSH is too low, the turnover of hydroperoxides by GSH peroxidase is incomplete, whereas excessive concentrations favour the spontaneous formation of GSSG. Owing to this spontaneous oxidation of GSH, the strictly parallel treatment of the two portions of a.sample (with and without GSH peroxidase) is mandatory.

\section{Addition of $\mathrm{GSH}$ peroxidase}

The concentrations of GSH peroxidase chosen in the assay procedures are sufficient to guarantee the complete turnover of $>0.1 \mathrm{mmol} / \mathrm{t}$ t-butyl hydroperoxide and $>0.1 \mathrm{mmol} / 1$ of a mixture of peroxidized, free fatty acids under the given reaction conditions.

\section{Recovery, sensitivity}

The recovery of t-butyl hydroperoxide and of peroxidized, free fatty acids is listed in table 1 . The sensitivity is reasonably high: organic hydroperoxides can be specifically detected at a concentration as low as $0.9 \mathrm{nmol} / \mathrm{mg}$ lavage phospholipid (molar ratio of $0.00066)$ and $40 \mathrm{nmol} / \mathrm{g}$ wet weight.

Tab. 1. Recovery of t-butyl hydroperoxide and of a mixture of peroxidized, free fatty acids added to lavage fluid ( $25 \mathrm{nmol}$ hydroperoxide per $\mathrm{mg}$ lavage phospholipid) and to fresh lung tissue $(600 \mathrm{nmol} / \mathrm{g}$ wet weight) immediately prior to the complete assay procedure. As the time (latent period) is increased between mixing of peroxidized free fatty acids with roughly minced lung tissue at $0^{\circ} \mathrm{C}$ and the beginning of the first step of the assay procedure (homogenation with $\mathrm{HClO}_{4}$ ), there is rapid decrease in recovery.

\begin{tabular}{lll}
\hline & $\begin{array}{l}\text { Peroxidized } \\
\text { free fatty acids }\end{array}$ & $\begin{array}{l}\mathrm{t}-\text { Butyl } \\
\text { hydro- } \\
\text { peroxide }\end{array}$ \\
\hline $\begin{array}{l}\text { Lavage fluid } \\
(\mathrm{n}=4 ; \text { no latent period) }\end{array}$ & $94-100 \%$ & $86-92 \%$ \\
$\begin{array}{l}\text { Tissue homogenate } \\
(\mathrm{n}=4 ; \text { no latent period })\end{array}$ & $89-94 \%$ & $86-91 \%$ \\
$\begin{array}{l}\text { Latent period } 5 \min (n=1) \\
\text { Latent period } 10 \min (n=1)\end{array}$ & $91 \%$ & \\
Latent period $30 \min (n=1)$ & $14 \%$ & \\
\hline
\end{tabular}

Application to surfactant and lung tissue with and without peroxidative stress

When the assay was applied to lavages of normal rabbit lungs, the measured concentration of organic hydroperoxides was $41.7 \pm 8.6 \mathrm{nmol} / \mathrm{mg}$ phospholipid (mean \pm S.D.; $n=6$ ). The amount of hydroperoxide found in lavages of rabbits which had been exposed to a $100 \%$ oxygen atmosphere for $48 \mathrm{~h}$ is only insignificantly higher: $49.7 \pm 18.7 \mathrm{nmol} / \mathrm{mg}$ phospholipid $(n=6)$. If, however, lavages from normal lungs were exposed to $\mathrm{FeCl}_{3}$ and ascorbic acid for $20 \mathrm{~h}$ (26), the amount of hydroperoxides increased dramatically: $724 \pm 109 \mathrm{nmol} / \mathrm{mg}$ phospholipid, i.e. a molar ratio of $0.53 \pm 0.08$, was found ( $\mathrm{n}$ $=4)$. When lung tissue homogenate of normal rabbits was assayed, no organic hydroperoxides were detected by the described method $(n=10)$. Even a challenge of normal lungs with $\mathrm{FeCl}_{3}$ and ascorbic acid for $20 \mathrm{~h}$ (after homogenization of the tissue with phosphate buffer or with perchloric acid and subsequent neutralization) did not result in detectable amounts of hydroperoxides $(n=3)$. 


\section{Discussion}

The described assay, employing GSH peroxidase and GSH reductase, specifically detects exogenously added organic hydroperoxides in the alveolar surfactant system and in lung tissue homogenate with good recovery. The sensitivity is high enough to detect endogenous organic hydroperoxides in the bronchoalveolar lavage fluid from normal lungs. The marked increase of hydroperoxides after incubation of the surfactant material with $\mathrm{FeCl}_{3}$ and ascorbic acid in vitro encouraged us to measure hydroperoxide levels in the surfactant system in situations of increased peroxidative stress in vivo.

Though GSH peroxidase in general shows broad specifity towards the hydroperoxide-bearing substrate, there are doubts whether peroxidized fatty acids in phospholipids are converted by this enzyme (26). At least the lipoxygenase accessible regions of di-linoleoyl-lecithin (regions peroxidized after incubation with soybean lipoxygenase) are a poor substrate for GSH peroxidase (33). In view of this observation, the high amount of GSH peroxidase detectable hydroperoxides found after $\mathrm{FeCl}_{3}$ /ascorbate incubation of the lavage fluid is surprising. Calculated in relation to the lavage phospholipids, which account for $>80 \%$ of the total lavage lipids (34), a molar ratio of 0.53 (hydroperoxide per phospholipid) is found. This suggests that either $\mathrm{FeCl}_{3}$ /ascorbate-induced hydroperoxides in phospholipids are better accessible to the GSH peroxidase, or that this unspecific peroxidation procedure is followed by extensive fragmentation of the phospholipids.
With respect to lung tissue homogenate, organic hydroperoxides cannot be detected even after a massive peroxidative attack with $\mathrm{FeCl}_{3}$ /ascorbic acid. Two explanations are offered:

a) Experiments measuring lipid peroxidation by the thiobarbituric acid method $(35,36)$ have suggested a cytosolic peroxidation inhibitory factor in lung tissue. In accordance with these data no ethane and pentane could be detected in the headspace of lung tissue homogenate incubated with $\mathrm{FeCl}_{3}$ /ascorbate for $20 \mathrm{~h}$ (detection limit = 1 pmol volatile hydrocarbon ${ }^{1}$ ).

b) The described assay measures the "steady state level" of organic hydroperoxides, which may be low in lung tissue because of rapid enzymatic or non-enzymatic degradation. In this context transition metals and haem groups must be considered to play a major role $(37-39)$. Rapid peroxide decomposition would also explain the nonrecovery of the surfactant hydroperoxides in the whole lung homogenate $(70-130 \mathrm{nmol} / \mathrm{g}$ wet lung weight were to be expected when calculated on the basis of the hydroperoxide content of the lavage fluid), and the rapidly decreasing recovery of peroxidized fatty acids added to freshly minced lung tissue, even at $0^{\circ} \mathrm{C}$ (tab. 1).

\section{Acknowledgements}

The authors express their appreciation to Mrs. K. Klapettek for her excellent technical assistance.

Supported by the Deutsche Forschungsgemeinschaft (Schwerpunktprogramm „Posttraumatisches Lungenversagen“).

I) W. Seeger and K. Remy: non-published results.

\section{References}

1. Frank, L. \& Massaro, D. (1980) Amer. J. Med. 69, 117-126.

2. Kuehl, F. A., Jr., Ham, E. A., Egan, R. W., Dougherty, H. W., Bonney, R. J. \& Humes, J. L. (1982) in Pathology of Oxygen (Autor, A. P., ed.), pp. 175-190, Academic Press/ New York.

3. Balentine, J. D. (1982) Pathology of Oxygen Toxicity, Academic Press/New York.

4. Pryor, W. A. (1978) Photochem. Photobiol. 28, 787-801.

5. Goldstein, B. D. (1979) in Oxygen Free Radicals and Tissue Damage (Ciba Foundation Symposium 65 (new series)), pp. 295-319, Excerpta Medica/Amsterdam, Oxford, New York.

6. Sagai, M., Ichinose, T., Oda, H. \& Kubota, K. (1981) Lipids $16,64-67$.

7. Leung, H. W. \& Morrow, P. E. (1981) Res. Commun. Chem. Pathol. Pharmacol. 31, 111-118.

8. Crystal, R. G., Bitterman, P. B., Rennard, S. I., Hance, A. J. \& Keogh, B. A. (1984) N. Engl. J. Med. 310, 154-166 and $235-244$

9. Johnson, K. J., Fantone, J. C., III., Kaplan, J. \& Ward, P. A. (1981) J. Clin. Invest. 67, 983-993.

10. Weiss, S. J., Young, J., LoBuglio, A. F., Slivka, A. \& Nimeh, N. F. (1981) J. Clin. Invest. 68, 714-721.
11. Cochrane, C. G., Spragg, R. G., Revak, S. D., Cohen, A. B. \& McGuire, W. W. (1983) Amer. Rev. Respir. Dis. 127, S25-S27.

12. Kohn, H. I. \& Liversedge, M. (1944). J. Pharmacol. Exp. Ther. 82, 292-300.

13. Ohkawa, H., Ohishi, N. \& Yagi, K. (1979) Anal. Biochem. 95, 351-358.

14. Chio, K. S. \& Tappel, A. L. (1969) Biochemistry 8 , 28212827.

15. Purdy, R. E. \& Tappel, A. L. (1979) J. Chromatogr. 170, 217-220.

16. Riely, C. A., Cohen, G. \& Liberman, M. (1974) Science 183, 208-210.

17. Dillard, C. J. \& Tappel, A. L. (1979) Lipids 14, 989-995.

18. Recknagel, A. O. \& Ghoshal, A. K. (1966) Exptl. Mol. Pathol. $5,413-442$.

19. St. Angelo, A. J., Ory, A. L. \& Brown, L. E. (1975) J. Am. Oil Chem. Soc. 52, 34-39.

20. Bunyan, J., Murrell, E. A., Green, J. \& Diplock, A. T. (1967) Br. J. Nutr. 21, 475-495.

21. Gray, J. I. (1979) J. Am. Oil Chem. Soc. 55, 539-546.

22. Christopherson, B. O. (1968) Bipchim. Biophys. Acta 264, 35-46. 
23. Günzler, W. A., Vergin, H., Müller, I. \& Flohé, L. (1972) Hoppe-Selyer's Z. Physiol. Chem. 353, 1001-1004.

24. Sies, H., Gerstenecker, C., Summer, K. H., Menzel, H. \& Flohé, L. (1974) In: Glutathione (Flohé, L., Benöhr, H. C., Sies, H., Waller, H. D. \& Wendel, A., eds.) pp. 261-275, G. Thieme Publishers/Stuttgart.

25. Heath, R. L. \& Tappel, A. L. (1976) Anal. Biochem. 76, 184-191.

26. Flohé, L. (1982) In: Free Radicals in Biology, Vol. V (Pryor, W. A., ed.), pp. 223-253, Academic Press/New York.

27. Günzler, W. A., Kremers, H. \& Flohé, L. (1974) Z. Klin. Chem. Klin. Biochem. 12, 444-448.

28. King, J. R. \& Clements, J. A. (1972) Am. J. Physiol. 223, 715-726.

29. Hamberg, M. \& Samuelsson, B. (1967) J. Biol. Chem. 242, 5329-5335.

30. Dumelin, E. E. \& Tappel, A. L. (1977) Lipids 12, 894-900.
31. Kikkawa, J., Aso, J., Yoneda, K. \& Smith, F. (1976) In: Lung Cells in Disease (Bouhuys, A., ed.) pp. 139-146, Elsevier/ North-Holland Biomedical Press.

32. Bergmeyer, H. U. (1970) Methoden der enzymatischen Analyse, p. 1605, Verlag Chemie, Weinheim/Bergstraße.

33. Grossmann, A. \& Wendel, A. (1983) Eur. J. Biochem. /35, $549-552$.

34. Mason, R. J. (1976) In: The Biochemical Basis of pulmonary function (Crystal, R. G., ed.) pp. 127-169, Marcel Dekker/ New York.

35. Gupta, G. S. D., Kaw, J. L. \& Krishna Murti, C. R. (1979) Arch. Environm. Health 34, 324-327.

36. Wright, J. R., Colby, H. D. \& Miles, P. A. (1981) Arch. Biochem. Biophys. 206, 296-301.

37. Maier, V. P. \& Tappel, A. L. (1959) J. Am. Oil Chem. Soc. $36,12-15$.

38. O'Brien, P. J. (1969) Can. J. Biochem. 47, 485-499.

39. Dumelin, E. E. \& Tappel, A. L. (1977) Lipids 12, 894-900.
Dr. Werner Seeger

Medizinische Klinik

Klinikstraße 36

D-6300 Gießen 
